\title{
The role of stakeholders' interests management mechanism in the transport services market development
}

\author{
V.P. Tretyak ${ }^{l}$, G.P. Rekun $^{l}$, K.O. Andreieva ${ }^{l^{*}}$, and M.S. Bieliai ${ }^{l}$ \\ ${ }^{1}$ V.N. Karazin Kharkiv National University (Kharkiv, Ukraine)
}

\begin{abstract}
Article deals with stakeholder's interests analysing in transport services market. The main goal of the paper is to propose the best solution for current stakeholders' conflicts in transport market. Common groups of stakeholders in transport services market are identified. Stakeholder's interests are highlighted and analysed. Social, corporate, business, ecological, and political interests are compared. One-level and inter-level conflicts of stakeholders' interests are figured out. Analysis according to Importance and Influence Stakeholder Analysis framework has been made. In particular, it is determined that the stakeholder's conflicts are complex and entailed the emergence of a conflict web. A set of tools for most effective solving current problem and achieving existence opportunities are selected. Searching for a "win-win" solutions is proposed as the basic strategy for resolving stakeholders' conflicts of the transport services market, achieving the goals of sustainable development, and acceleration of European integration processes.
\end{abstract}

Transformation processes in modern economic systems contribute to the creation of disparities and discontinuities in the chains between key players in any market - consumers and producers of goods and services. The imbalance of interests and tools for their harmonization is the main reason of it. This problem becomes of particular importance for transport enterprises taking into account the role of the transport system and its participants in ensuring the development of the state.

The purpose of the article is identifying the key stakeholders of the transport services market in Ukraine and the best tools of forming a mechanism for resolving conflicts between them.

\section{Main part}

An effective and flexible system for coordinating stakeholders' interests should be created for the successful operation and development of the transport services market. For this purpose, it is advisable to classify the main stakeholders by the importance of their participation in the process and to identify their priority groups, interests and possible contradictions. A mechanism for coordinating stakeholders' interests is developed on the basis of the above [1].

\footnotetext{
* Corresponding author: andreeva@karazin.ua
} 
Consider the stakeholder classification on the transport services market example (Fig. 1). The key stakeholders of this market include the state (the main regulator), transport enterprises (transport corporations and small transport companies), states with transport links (main partners during the carriage), employees of transport companies, suppliers (vehicles, components, energy carriers, fuel, related products) and consumers of transport services. The effective interaction between them and the management of their interests are the key to the sustainable development of the transport services market in Ukraine.

Economic, social, ecological, and political interests can be identified as the most important for the activities of transport companies. [2]. Also, they are divided into: interconnected, coherent, or conflicting. That depends on the synergistic effect for each group.

The existing in our country model of finding a consensus and of developing a transport system (tools, set of approaches) does not gives a positive result. This requires a change in the approach to concentrating on subjects (stakeholder groups) for effective managing conflicts of interest between them.

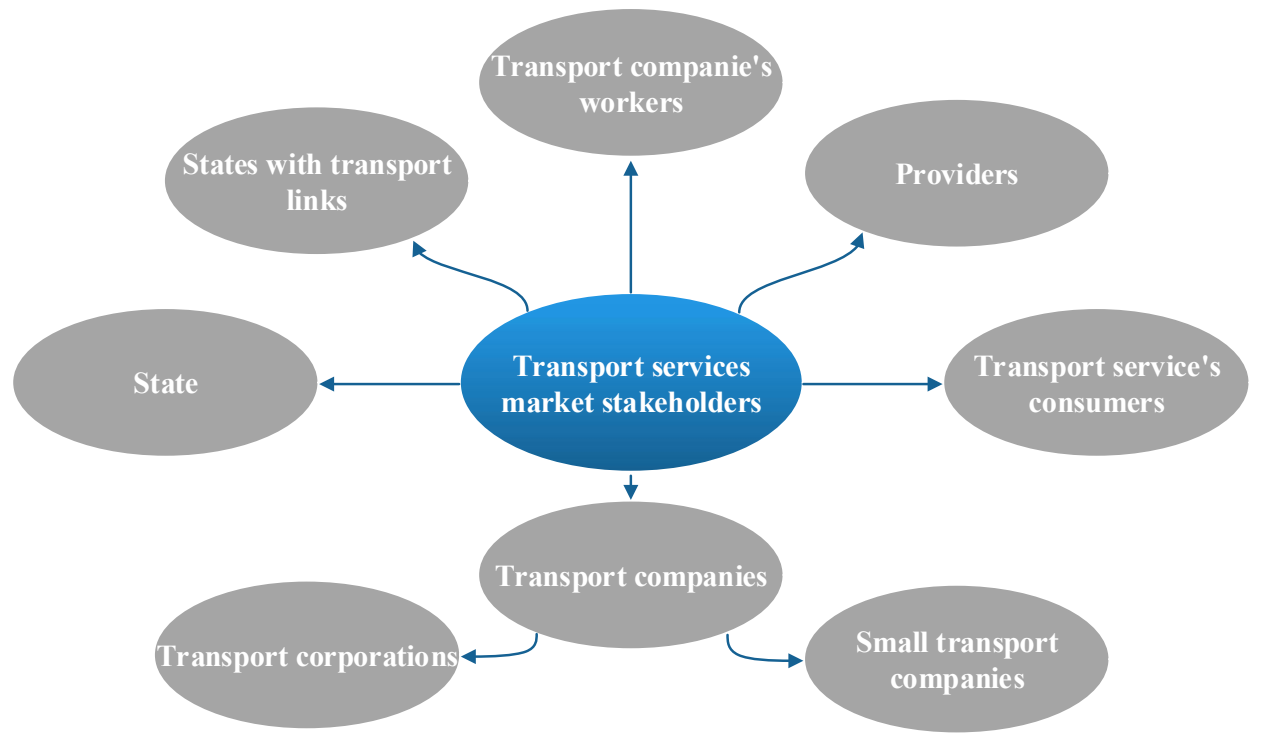

Fig. 1. Classification of The transport market stakeholders [1]

In general, the interests of certain stakeholders can be grouped in the following box:

- Economic;

- Social

- Ecological;

- Political;

We considered the thesis that characterizes the interests of each stakeholders' group by the proposed box.

Table 1. The transport market stakeholders' interests

\begin{tabular}{|l|l|l|l|l|}
\hline & \multicolumn{1}{|c|}{ Economic } & \multicolumn{1}{|c|}{ Social } & \multicolumn{1}{|c|}{ Ecological } & \multicolumn{1}{c|}{ Political } \\
\hline State & $\begin{array}{l}\text { Reduce the cost of } \\
\text { maintaining and } \\
\text { refurbishing } \\
\text { transport }\end{array}$ & $\begin{array}{l}\text { Ensuring social } \\
\text { standards and } \\
\text { fulfilling their } \\
\text { social function. }\end{array}$ & $\begin{array}{l}\text { Ensuring } \\
\text { environmental } \\
\text { norms, } \\
\text { environmental }\end{array}$ & $\begin{array}{l}\text { Preservation of } \\
\text { state sovereignty, } \\
\text { border protection, } \\
\text { political and }\end{array}$ \\
\hline
\end{tabular}




\begin{tabular}{|c|c|c|c|c|}
\hline & \begin{tabular}{|lr} 
infrastructure, and \\
increasing & the \\
amount & of \\
collected taxes.
\end{tabular} & & 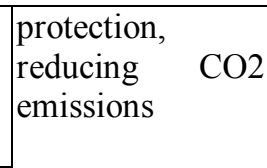 & $\begin{array}{l}\text { information } \\
\text { security }\end{array}$ \\
\hline $\begin{array}{l}\text { State with the } \\
\text { transport links }\end{array}$ & $\begin{array}{l}\text { Reduce the cost of } \\
\text { transport systems } \\
\text { integrating. }\end{array}$ & $\begin{array}{l}\text { Protecting own } \\
\text { citizens while } \\
\text { using Ukrainian } \\
\text { transport. }\end{array}$ & & \\
\hline $\begin{array}{l}\text { Transport } \\
\text { corporations }\end{array}$ & $\begin{array}{lr}\text { Providing } & \text { stable } \\
\text { profits } & \text { and } \\
\text { company } & \end{array}$ & Compliance with & - & $\begin{array}{l}\text { Strengthening } \\
\text { influence on } \\
\text { society, getting of } \\
\text { monopoly } \\
\text { positions. }\end{array}$ \\
\hline $\begin{array}{l}\text { Small transport } \\
\text { companies }\end{array}$ & $\begin{array}{llr}\text { reducing } & & \text { costs } \\
\text { (taxes, } & \% & \text { on } \\
\text { loans, } & \text { salaries, } \\
\text { etc.) } & & \end{array}$ & $\begin{array}{l}\text { legislation and } \\
\text { social standards. }\end{array}$ & - & $\begin{array}{l}\text { Saving } \\
\text { positions, } \\
\text { protection } \\
\text { monopoly, from } \\
\text { dumping } \\
\text { admin impact. }\end{array}$ \\
\hline $\begin{array}{l}\text { Transport } \\
\text { companies } \\
\text { workers }\end{array}$ & High salary. & $\begin{array}{l}\text { Good working } \\
\text { conditions, high } \\
\text { social standards, } \\
\text { corporate culture. }\end{array}$ & \multicolumn{2}{|c|}{$\begin{array}{l}\text { Safety of life and health while } \\
\text { performing their duties. }\end{array}$} \\
\hline Providers & 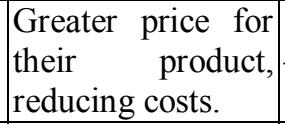 & - & - & $\begin{array}{l}\text { Levels of rights } \\
\text { for suppliers' lack } \\
\text { lobbying. }\end{array}$ \\
\hline Consumers & $\begin{array}{|lr|}\text { Reduce } & \text { the price } \\
\text { of } & \text { transport } \\
\text { services. } & \end{array}$ & $\begin{array}{l}\text { High quality of } \\
\text { services }\end{array}$ & \multicolumn{2}{|c|}{$\begin{array}{l}\text { Safety of life and health during } \\
\text { using transport services. }\end{array}$} \\
\hline
\end{tabular}

Source: $[1,3]$

A detailed study of each stakeholder's interests does not reveal a synergistic effect on the level of stakeholders. It is understood that only interests of one direction can be conflicted, such as the economic interests of users with the economic interests of transport corporations. However, there is a situation where the interests of different levels conflict through the tools, which these interests are achieved. So, the ecological interests of the state conflict with the economic interests of transport companies through instruments (ecological requirements and taxes). At the same time, it exacerbates the conflict of economic interests (one level) of the company, user and company's employee.

As Figure 2 shows, a significant proportion of stakeholders is important for the transport services market in Ukraine, but only three categories differ by grate influence: the state, transport corporations and suppliers. It is these groups of stakeholders who can independently defend their interests, which forms two additional threats to conflicts.

First, the conflicts that arise between these stakeholders considerably exhaust the resource that could be used in a positive way. Secondly, interested parties that do not have such influence automatically fall into the dependence on "strong" players. A similar situation of power balance in a conflict of interest exists in corporate governance. In particular, conflict between minority and majority shareholder. Therefore, it is proposed to use a special toolkit for corporate governance to manage conflicts of this level [5]. 


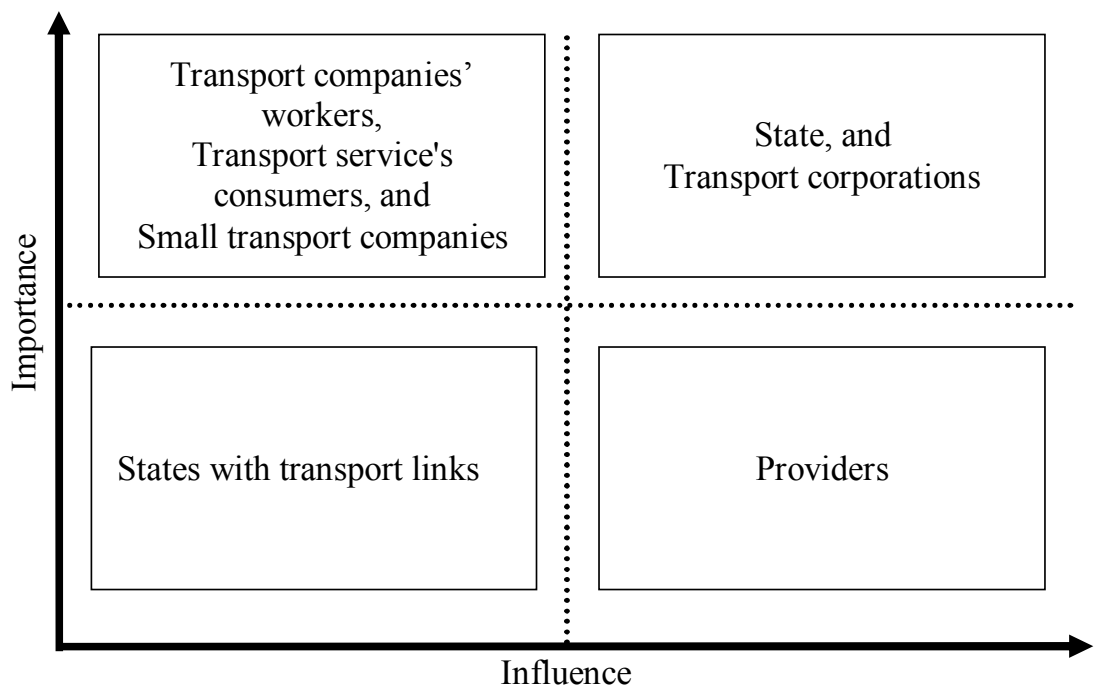

Fig. 2. Classification of stakeholders by Influence and Importance [1,4]

To achieve the goals of sustainable development of the state, including in the transport sector, and acceleration of European integration processes it is proposed not to seek compromise solutions but to meet the needs of each group using current world experience and corporate governance practices. It must be understood that a comprehensive system will not only overcome the gaps that arise from conflicts, but also strengthen the already existing positive synergistic effect. Therefore, we recommend the use of the following tools to resolve the problem [2]:

- eco-lending (can simultaneously meet the economic interests of corporations and the state's ecological interests and, as a result, reduce the intensity of the conflict between business, users and workers).

- the use of international standards, not only in technological aspects, but also in management (for solving the conflict between corporations and small businesses, meeting the social and environmental needs of the state and the interests of the state on the combination).

- "Smartization" of the transport services market (at the same time, it satisfies the needs of the state, economic needs of business, social and political needs of users and workers).

- public-private partnership instruments (while satisfying the economic, political, social and ecological interests of the state, the economic needs of corporations, the political needs of small businesses, and the political, economic and social needs of users and workers).

- ESCO-mechanism (allows satisfying simultaneously the economic interests of corporations and the state's ecological interests, economic interests of users and the political and ecological interests of workers).

- SROI tool and social investment (can balance the social and economic interests of all stakeholders);

- marketing and business tools.

\section{Conclusions}


In conclusion, we can say that in modern conditions, ensuring the efficient functioning of the transport services market and the stable competitive advantages of its participants are ensured by the coordination (management) of their key interests. However, today in Ukraine it is difficult to achieve the required balance, because the previous instruments are not effective. Accordingly, there is a need for the formation of a new effective mechanism for management conflicts between the stakeholders' interests and the implementation of its instruments at different levels of management.

\section{References}

1. Development strategy of PJSC "Ukrzaliznytsya" for 2017 - 2021 years. Retrieved from: http://publications.chamber.ua/2017/Infrastructure/Session_1_Kravtsov.pdf [in Ukrainian] 2. Babina, O.E., Strelkov, O.V. "Investments: practice and experience". Interests of transport service providers 16, 15-21 (2017)

3. Schaar, David, and Lance Sherry. "Analysis of airport stakeholders." Integrated Communications, Navigation, and Surveillance Conference Proceedings. IEEE, (2010)

4. McCormick, D., Stakeholder Analysis, Paper Presented in REME Training Workshop (1997)

5. Landini, Fabio, and Ugo Pagano. "Stakeholders' conflicts and corporate assets: an institutional meta-complementarities approach." Socio-Economic Review (2018). 